\title{
IMPACT OF FIRE ON NATURAL REGENERATION IN PEAT
}

\author{
Bambang Hero Saharjo ${ }^{1)^{*}}$ and Ati Dwi Nurhayati ${ }^{21}$ \\ 1)Forest Fire Laboratory, Faculty of Forestry, Bogor Agricultural University, Indonesia, \\ PO.BOX 168 Bogor, Phone: 62251421929, Fax: 62251621256, \\ 2)Alumni, Faculty of Forestry, Bogor Agricultural University, Indonesia, \\ PO.BOX 168 Bogor, Phone: 62251421929, Fax: 62251621256
}

\begin{abstract}
Fire is one of the most effective tools in disappearing vegetation community, where it was depend on the characteristics of burning itself and also the performance of the site being burnt. Previous research in mineral soils showed that repeated burning occurred at the same place trend to clean the vegetation which finally leads to have the land with lower number and quality of species left, while in peat land it was not fully understood. The research objective is to understand the vegetation dynamics following peat fires in the fibric peat type at the land preparation area using fire belong to the local community located in the Pelalawan district, Riau province, Indonesia during the dry season in the year 2001. Before slashing and drying, 10 tree species and 4 species of understorey vegetation found. The site was dominated by Uncaria glabrata at seedling stage, Garcinia rostrata at sapling stage, Shorea macrophylla at pole stage and Pandanus immersus at understorey. After slashing and followed by 4 weeks drying then continued by burning with high flame temperature range from $875^{\circ} \mathrm{C}$ to $900^{\circ} \mathrm{C}$, it had been found that 3-months following burning the site was dominated by Garcinia rostrata at seedling stage and Cyperus halpan at understorey, while 6-months following burning the site was dominated by Eugenia jambos at seedling stage and Cyperus halpan at understorey. Three months following burning species left to be only 4 species with 115 individual/ha (3 species from original and 1 new species emerge), and at 6 months following burning still 4 species left with 250 individualha. Meanwhile in understorey vegetation, 3 months following burning the species increased to be 7 species with 746 individual/ha (3 species left unchanged, 1 species disappeared and 4 new species emerge) and 6 months following burning the species left still 7 species with 1235 individual/ha. This means that fire stimulate the increasing number of understorey vegetation.
\end{abstract}

Keywords: Peat fires, peat type, flame, natural regeneration, human

\section{INTRODUCTION}

In the most comprehensive study of the fires impact on the forest (Schindler, 1989), the researchers found that only $11 \%$ of the total forest area affected by fire was undisturbed primary forest, and that when this type of forest burns, only undergrowth is consumed, allowing full recovery of plant life within a few years.

Woods (1987) reported that the species composition of post-fire regeneration is related to the degree of canopy damage and resulting light level at the forest floor. High ground-level sunlight encourages pioneer species to sprout, disrupting the growth of tree seedlings normally associated with primary and secondary forests. Their effect is exacerbated in areas where hot fires destroy seedlings and viable seeds in the forest floor litter.
Ten years after the fires, ITTO-funded researchers studied regeneration in burned areas and reported that a variety of plant communities had grown, ranging from comparatively well-structured forest with wide species diversity to almost pure stands of pioneer species (Hess, 1994). The ITTO group was able to accelerate regeneration by killing pioneers species and planting seedlings of commercially valuables species. Vegetation ecologist have studied natural regeneration in abandoned Sweden plots and other forest clearings, providing insight into postregeneration. One group found that after 30-years of natural regeneration in an abandoned pepper plantation, the resulting secondary forest was physiognomically indistinguishable from the primary lowland dipterocarp forest but different in floristics composition and structure (Kartawinata et al., 1981).

Previous research in mineral soils showed that repeated burning occurred at the same place trend to clean the vegetation which finally leads to have the land with lower number and quality of species left. While in peat land it was not fully understood. This paper present the information on fire impact to the natural regeneration of peat especially in fibric site.

\footnotetext{
* Correspondence: B. Hero Saharjo Forest Fire Laboratory, Faculty of Forestry, Bogor Agricultural University, Indonesia, PO.BOX 168 Bogor, Phone: 62251421929, Fax: 62251621256, e-mail: saharjo@indo.net.id
} 


\section{MATERIALS AND METHODS}

\section{Site and Time Period}

Research was conducted in the period of August 2001 until July 2002 in the peat land area belong to the community of Pelalawan village, Pelalawan sub-district, Pelalawan district, Riau Province.

Based on the vegetation analysis shown that the research site was dominated by shrubs and ferns, vegetation found was Shorea macrophylla, Macaranga pruinosa, Ficus sundaica, Stenochlaena palustris, Parastemon uruphyllus, Baccaurea pendula, Nephorlepis flaccigera and Gleinchenia linearis.

Climate in Pelalawan district cannot be separated from Riau province condition, generally the site was tropical climate with annually rainfall range between $2500-3000$ $\mathrm{mm}$ with daily temperature between $22^{\circ} \mathrm{C}$ to $31^{\circ} \mathrm{C}$. According to data made by Meteorological and Geophysical Agency, Ministry of Transportation, annually rainfall in the period between January-December 2001 in the site was $3794.5 \mathrm{~mm}$ that accompanied by 86 rainy days.

\section{Sampling Data}

The research was conducted in the field and at laboratory scale. Two (2) plots of $400 \mathrm{~m}^{2}(20 \mathrm{~m} \mathrm{X} 20 \mathrm{~m})$ each with different characteristics is established at fibric site.

Before slashing and burning conducted, soil sampling, environmental condition measurement, and fuel characterization. Following those activity slashing was conducted where big $\log$ (diameter more than $10 \mathrm{~cm}$ ) send out from the plot. Slashed logs and branching was separated through the plot. During slashed period (drying process) fuel characterization being conducted at different time measurement accompanied by environmental condition monitoring such as temperature, relative humidity and wind speed. Following slashing was drying for 4 a period of 4 weeks as it usually done by the community.

\section{Activities conducted before burning}

Three sub - plot of $2 \mathrm{~m}^{2}(2 \mathrm{~m} \times 1 \mathrm{~m})$ in all the plot of $400 \mathrm{~m}^{2}$ at fibric site was established in order to measure fuel characterístics such as fuel moisture, fuel bed depth, and fuel load.

Three samples of 100 gram each of materials found in the subplots (litter, leaves, branches, and logs) were taken and used as samples for moisture content measurement. Samples taken put in the oven and dried for 48 hours at $75^{\circ} \mathrm{C}$ (Clar and Chaten, 1954). Fuel moisture content estimated through dry weight based measurement.

Fuel load was estimated through the amount of plants materials both living and dead found in $\mathbf{n}$ the subplot which were collected, separated and weighed.

Fuel bed depth was measured by the average height of the association of living and dead plant materials of various sizes and shapes in the subplots.

\section{Activities conducted during burning}

Burning was conducted using circle method and allowing the fire to propagate naturally. Flame temperature at $0 \mathrm{~cm}$ and $1 \mathrm{~cm}$ under the peat surface were measured using data logger. The temperature censors were placed in the plot at two locations.

Rate of the spread of fire was measured by the average distance perpendicular to the moving flame front per minute, using a stopwatch and through video camera recording.

It was very difficult to measure the average length of the flame directly in the burning condition, and then flame height was calculated through video camera recording.

\section{Activities conducted after burning}

Fuel left in the plot is measured by establishing 5 subplot $1 \mathrm{~m}^{2}$ in every plot. Those fuel left in the plot is weighted and checked.

Soon, following burning, heat penetration depth is measured by digging 5 sub-plot $400 \mathrm{~cm}^{2}$ each in all the plots until $30 \mathrm{~cm}$ depth.

Fire intensity was calculated using Byram's equation (Chandler et al, 1983), FI $=273(\mathrm{~h})^{2.17}$, where FI is fire intensity $(\mathrm{kW} / \mathrm{m})$ and $\mathrm{h}$ is flame length $(\mathrm{m})$

\section{Vegetation Changing}

In order to know the vegetation structure and composition changing then $25 \mathrm{~m}^{2}(5 \mathrm{~m} \times 5 \mathrm{~m})$ sub-plot was established in the plot of $400 \mathrm{~m}^{2}$. In these sub-plots, all seedling, sapling, pole and trees and also understorey vegetation was calculated its species and number. Criteria used for seedling, sapling, pole and trees (Kusmana and Istomo, 1995) was as follows:

Seedling means vegetation that has $1.5-\mathrm{m}$ height.

Sapling means vegetation that has $1.5-\mathrm{m}$ height until seedling with $10-\mathrm{cm}$ diameter.

Pole means vegetation that has $10-20 \mathrm{~cm}$ diameter.

Trees means vegetation that has $>20-\mathrm{cm}$ diameter.

Before slashing, all seedling, sapling, pole, trees and undergrowth vegetation found in the sub-plot was calculated its species and number. Following slashing was drying for 4-weeks which continued by burning.

\section{Activities conducted following burning}

Following burning in the period of 1 month, 3 months and 6 months, all seedling, sapling, pole, trees and undergrowth vegetation found in the sub-plot was calculated its species and number.

\section{Important Value Index (IVI)}

Vegetation analysis is the way to study species composition and vegetation structure in one ecosystem (Soerianegara and Indrawan, 1998). In the vegetation analysis it was calculating Important Value Index. According to Odum (1971), IVI was numbering density 
relative (DR), frequency relative (FR) and dominance relative (DR).

$$
\mathrm{IVI}=\mathrm{DR}+\mathrm{FR}+\mathrm{DR}
$$

- IVI for trees and pole was: DR + FR + DR

- IV for seedling, sapling and undergrowth vegetation was

: DR + FR, where

- Species density (D): Total number of a species/sample unit size x $100 \%$

- Species density relative (DR): Species density/all species density $\times 100 \%$

- Species frequency (F): Number of plot found for a species/ sample unit size x $100 \%$

- Species frequency relative (FR): Species frequency/ all species frequency $\times 100 \%$

- Dominancy species (D):

* Trees, pole and sapling: Basal area/plot size

* Seedling, and under growth vegetation: Canopy covering species size/plot size

* Dominance relative (DR): Dominance of a species/all species dominance $x 100 \%$

\section{Species Richness}

Species richness was a species number in a community. In order to predict species richness, Margaleff (Ludwig and Reynolds, 1988) formula used as follows:

$$
\begin{aligned}
R=(S-1) /(\ln (n)) & \\
\text { Where, } R & =\text { Richness Index } \\
S & =\text { Total species found } \\
n & =\text { Total individual number }
\end{aligned}
$$

\section{Species Diversity}

Species richness used to compare two communities, to study the effect of biotic disturbing and to know succession stage. Diversity changing can be calculated by using Shannon-Weiner (Ludwig and Reynolds, 1988) that was:

$$
\begin{aligned}
& \mathrm{H}^{\prime}=-\sum(\mathrm{ni} / \mathrm{N}) \times \log (\mathrm{ni} / \mathrm{N}) \\
& \text { Where, } \mathbf{H}^{\prime}=\text { Diversity Index } \\
& \mathrm{N}=\text { Total number all individual } \\
& \mathrm{ni}=\text { Number of individual within a species } \\
& \text { in sample plot }
\end{aligned}
$$

\section{Evenness}

Evenness concept would like to show the degree of evenness of individual abundance between species. Evenness scaling was an indicator for signing dominancy between species within community. If every species have the same individual number, then those communities have maximum value. Meanwhile if in the community there was found dominancy or sub-dominancy species means that community have evenness with minimum value. Evenness formula (Ludwig and Reynolds, 1988) was:

$$
E=H^{\prime} /(\ln (S))
$$

Where, $\mathrm{E}=$ Evenness number $(0-1)$

$H^{\prime}$ = Shannon-Weiner Diversity Index

$\mathrm{S}=\sum$ all species within community

\section{Index of Similarity}

The changing of vegetation community following fire can be compared using community association analysis through following formula:

$$
\begin{aligned}
\text { IS }=(2 \mathrm{~W} /(\mathrm{a}+\mathrm{b})) \times 100 \%, \\
\text { Where, IS }= \\
\mathrm{W}=\text { Index o similarity } \\
\text { Lower number or the same from two } \\
\mathrm{a}, \mathrm{b}= \\
\text { Total communities that compared } \\
\text { burning) and } \mathrm{b} \text { (following buming) }
\end{aligned}
$$

The highest IS value was $100 \%$ while the lowest was $0 \% .100 \%$ value if compared communities really the same, $0 \%$ value if two communities compared absolutely different. Generally, two communities was relatively the same if they have IS $\geq 75 \%$.

\section{Data Analysis}

A completely random design of variance was used to test for differences among subplots, based on the following model (Steel and Torrie 1981):

\section{$Y m n=U+T m+E m n$}

Where, $Y \mathrm{mn}$ = fuel and fire behavior parameter at $\mathrm{m}$ subplot in $\mathbf{n}$ replication

$\mathrm{U}=$ mean of the treatment population sampled

$\mathrm{Tm}=$ treatment (slashing, drying, burning)

$E m n=$ random component

To identify significant difference of fuel and fire behavior parameters among subplots $(\mathrm{p} \leq 0.05)$, the Duncan test was used (Steel and Torrie 1981).

\section{RESULTS AND DISCUSSION}

\section{Before Burning}

Temperature before burning was vary from $36{ }^{\circ} \mathrm{C}$ in plot 2 to $37^{\circ} \mathrm{C}$ in plot 1 , relative humidity vary from $52 \%$ in plot 2 to $53 \%$ in plot 1 and wind speed vary from 0.67 $\mathrm{m} /$ minute in plot 2 to $1.05 \mathrm{~m} /$ minute in plot 1 (Table 1 ).

Before burning fuel load found in the site in the range between 61.56 to 62.67 ton/ha; fuel moisture vary from 8.63 to $9.19 \%$ for dry leaves, $12.85-15.6 \%$ for dry branching and 84.75 to $85.6 \%$ for peat surface; while fuel bed depth was vary from 42.3 to $54.7 \mathrm{~cm}$ (Table 1).

Before slashing 15 species of trees from 12 families was found in the fibric peat site which was dominated by Euphorbiaceae family and nine (9) species from 9 families of under storey vegetation was found (Table 2 ).

Important Value Index of seedling was vary from 7.612 (Alstonia pneumathophora) to 91.003 (Uncaria glabrata), sapling was vary from 2.681 (Gomystylus bancanus) to 50.63 (Garcinia rostrata), pole was vary from 28.22 (Derris heterophylla) to 70.93 (Pandanus immersus) and underg storey vegetation was 300 made by Shorea macrophylla (Table 3). 
Table 1. Weather condition and Fire Behavior during burning

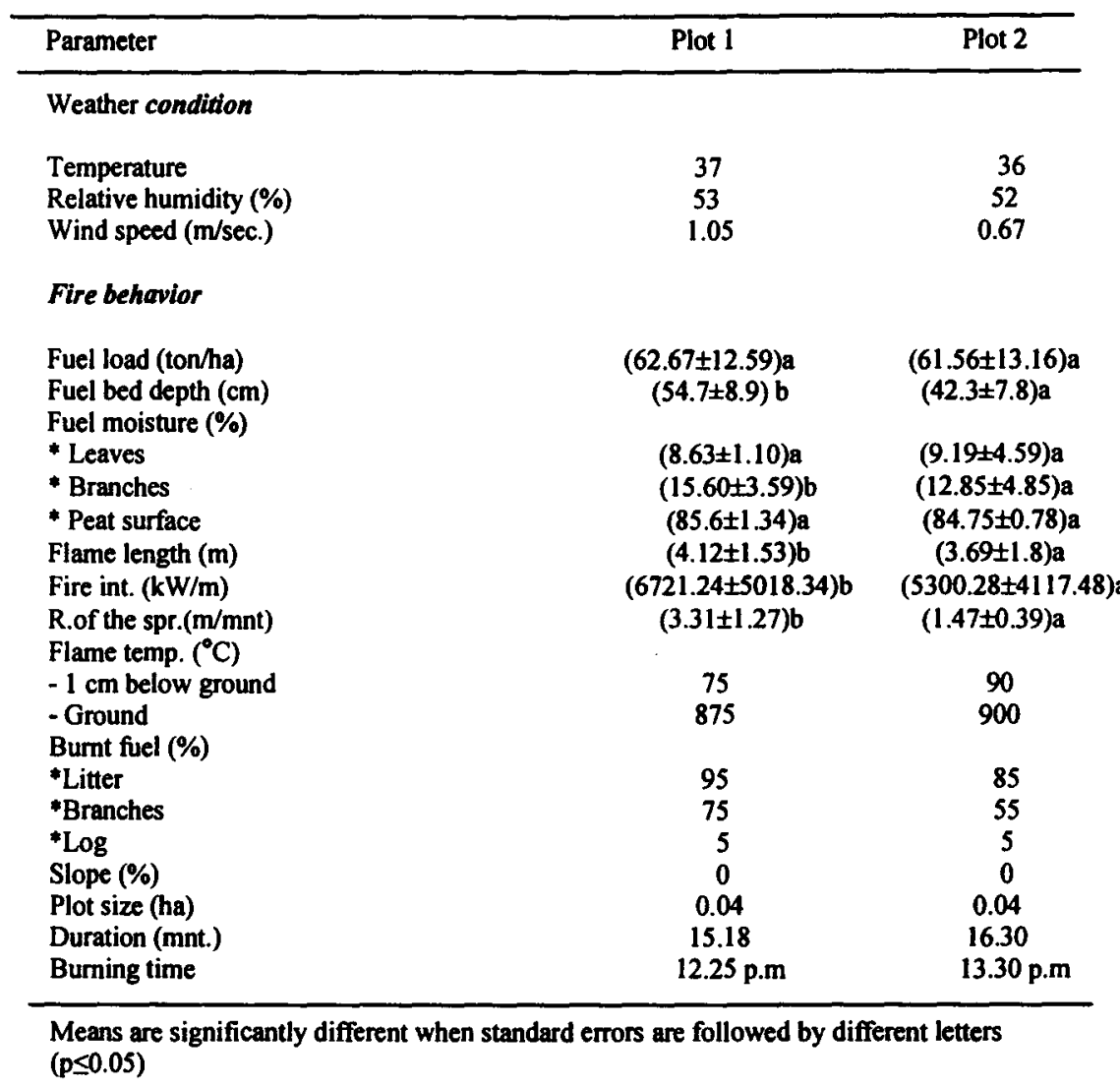

Table 2. Species trees and understorey vegetation found in the research site

\begin{tabular}{|c|c|c|c|}
\hline No. & Botanical name & Local name & Family \\
\hline & Species trees & & \\
\hline 1. & Alstonia spatulata & Basung & Apocynaceae \\
\hline 2. & Bredelia glauca & Ki Howo & Euphorbiaceae \\
\hline 3. & Calophyllum pulcherimum & Bintangur Onjem & Clusiaceae \\
\hline 4. & Euginia jambos & Jambu-jambu & Myrtaceae \\
\hline 5. & Ficus sundaica & Ara & Moraceae \\
\hline 6. & Galearia celebica & & Euphorbiaceae \\
\hline 7. & Ganua motleyana & Ketiau & Sapotaceae \\
\hline 8. & Garcinia rostrata & Asam Kandis & Clusiaceae \\
\hline 9. & Gonystylus bancanus & Gaharu Buaya & Thymelaeceae \\
\hline 10. & Litsea veluntina & Medang & Lauraceae \\
\hline 11. & Lophopetalum pachyphyllum & Perupuk & Celastraceae \\
\hline 12. & Neoscortechinia philippinensis & Nangka-nangka & Euphorbiaceae \\
\hline 13. & Parastemon urophyllus & Milas & Chrysobalanaceae \\
\hline 14. & Shorea macrophylla & Meranti & Dipterocarpaceae \\
\hline \multirow[t]{2}{*}{15.} & Timonius wallichianus & Cabe-cabe & Rubiaceae \\
\hline & Understorey vegetation & & \\
\hline 1. & Antidesma pentandrum & Kayu Lundu & Euphorbiaceae \\
\hline 2. & Cyperus halpan & Papayungan & Cyperaceae \\
\hline 3. & Derris heterophylla & Tubalau & Leguminasae \\
\hline
\end{tabular}



4. Erechthistes valeriantnifolia
Sintrong
Asteraceae
5. Melastoma malabathricum
Harendong
Melastomaceae
6. Nephorlepis radican
Paku Rawa
Oleandraceae
7. Pandanus immersus
Pandan Rawa
Pandanaceae
8. Stenochalaena palustris
Paku Hutan
Pteridaceae
9. Trycalsia sp.
Rayutan Cina
Rubiaceae

Table 3. Important Value Index Seedling, Sapling, Pole and Understorey vegetation before burning

\begin{tabular}{|c|c|c|c|c|c|c|c|c|}
\hline No & Botanical name & $\mathrm{D}$ (ind/ha) & DR (\%) & $\mathrm{F}$ & FR $(\%)$ & IVI & & \\
\hline & Seedling & & & & & & & \\
\hline 1. & Alstonia pneumathopora & 5 & 1.730 & 0.167 & 5.882 & 7.612 & & \\
\hline 2. & Alstonia scholaris & 8 & 2.768 & 0.250 & 8.824 & 11.592 & & \\
\hline 3. & Baccaurea pendula & 12 & 4.152 & 0.333 & 11.765 & 15.917 & & \\
\hline 4. & Bredelia glauca & 12 & 4.152 & 0.417 & 14.706 & 18.858 & & \\
\hline 5. & Ficus sundaica & 4 & 1.384 & 0.167 & 5.882 & 7.266 & & \\
\hline 6. & Litsea polyantha & 5 & 1.730 & 0.167 & 5.882 & 7.612 & & \\
\hline 7. & Litsea javanica & 7 & 2.422 & 0.250 & 8.824 & 11.246 & & \\
\hline 8. & Mangifera indica & 6 & 2.076 & 0.167 & 5.882 & 7.958 & & \\
\hline 9. & Parastemon uruphyllus & 18 & 6.228 & 0.417 & 14.706 & 20.934 & & \\
\hline \multirow[t]{2}{*}{10.} & Uncaria glabrata & 212 & 73.356 & 0.500 & 17.647 & 91.003 & & \\
\hline & & 289 & 100.000 & 2.833 & 100.000 & 200.000 & & \\
\hline 1. & $\begin{array}{l}\text { Sapling } \\
\text { Alstonia spatulata }\end{array}$ & 15 & 5.338 & 0.250 & 6.977 & 12.315 & & \\
\hline 2. & Bredelia glauca & 18 & 6.406 & 0.333 & 9.302 & 15.708 & & \\
\hline 3. & Lophopetalum pachyphyllum & 4 & 1.423 & 0.083 & 2.326 & 3.749 & & \\
\hline 4. & Euginia jambos & 15 & 5.338 & 0.333 & 9.302 & 14.640 & & \\
\hline 5. & Ficus sundaica & 11 & 3.915 & 0.250 & 6.977 & 10.891 & & \\
\hline 6. & Ganua motleyana & 15 & 5.338 & 0.333 & 9.302 & 14.640 & & \\
\hline 7. & Galearia celebica & 3 & 1.068 & 0.167 & 4.651 & 5.719 & & \\
\hline 8. & Garcinia rostrata & 90 & 32.028 & 0.667 & 18.605 & 50.633 & & \\
\hline 9. & Gonystylus bancanus & 1 & 0.356 & 0.083 & 2.326 & 2.681 & & \\
\hline 10. & Litse veluntina & 62 & 22.064 & 0.583 & 16.279 & 38.343 & & \\
\hline 11. & Neoscathecinia kingii & 4 & 1.423 & 0.083 & 2.326 & 3.749 & & \\
\hline 12. & Parastemon uruphyllus & 41 & 14.591 & 0.333 & 9.302 & 23.893 & & \\
\hline \multirow[t]{3}{*}{13.} & Timonius wallichianus & 2 & 0.712 & 0.083 & 2.326 & 3.037 & & \\
\hline & & 281 & 100.000 & 3.583 & 100.000 & 200.000 & & \\
\hline & Understorey vegetat & & & & & & & \\
\hline 1. & Derris heterophylla & 15 & 6.000 & 0.333 & 22.222 & 28.222 & & \\
\hline 2. & Nephorlepis radicans & 63 & 25.200 & 0.250 & 16.667 & 41.867 & & \\
\hline 3. & Pandanus immersus & 94 & 37.600 & 0.500 & 33.333 & 70.933 & & \\
\hline \multirow[t]{3}{*}{4.} & Stenochalaena palustris & 78 & 31.200 & 0.417 & 27.778 & 58.978 & & \\
\hline & & 250 & 100.000 & 1.500 & 100.000 & 200.000 & & \\
\hline & Pole & & & & & & & \\
\hline No & Botanical name & $\underset{\text { (ind/ha) }}{D}$ & DR $(\%)$ & $\mathrm{F}$ & FR $(\%)$ & $\mathrm{D}$ & DR & IVI \\
\hline \multirow[t]{2}{*}{1.} & Shorea macrophylla & 1 & 100.000 & 0.083 & 100.000 & 324.000 & 100 & 300.000 \\
\hline & & 1 & 100.000 & 0.083 & 100.000 & $324.000^{3}$ & 100 & 300.000 \\
\hline
\end{tabular}




\section{After Burning}

Flame length was vary from $3.69 \mathrm{~m}$ to $4.12 \mathrm{~m}$, where rate of the spread of fire vary from $1.47 \mathrm{~m} /$ minute to 3.31 $\mathrm{m} /$ minute, resulted flame temperature in the ground that vary from $875^{\circ} \mathrm{C}$ to $900^{\circ} \mathrm{C}$ and flame temperature $1 \mathrm{~cm}$ under the ground was vary from $75^{\circ} \mathrm{C}$ to $90^{\circ} \mathrm{C}$ Fire intensity as one component to understand how fire behave was vary from 5300 in plot 2 to $6721 \mathrm{~kW} / \mathrm{m}$ in plot 1 (Table 1).

\section{Important Value Index}

Three months following burning Important Value Index seedling in sapric plot was dominated by Eugenia jambos with IVI was $\mathbf{8 8 . 7 5 8}$ and Garcinia rostrata with IVI was 56.398, while Six months following burning it was dominated by Eugenia jambos with IVI was 102.945 followed by Parastemon uruphyllus with IVI was 34.571 (Table 4).

Important Value Index under storey vegetation three months following burning was dominated by Cyperus halpan with IVI was 83.789 followed by Stenochlaena palustris with IVI was 32.486 , while six months following burning it was dominated by Cyperus halpan with IVI was 69.779 followed by Pandanus immersus with IVI was 31.097 (Table 5).

\section{Species Richness (R)}

Three months following burning in Fibric 1, species richness of seedling was 0.71 , sapling was 0.0 , pole was 0.0 and under storey was 0.06 , while in Fibric 2, species richness of seedling was 0.53 , sapling was 0.0 , pole was 0.0 and under storey was 0.86 (Table 6).

Six months following burning in Fibric 1, species richness of seedling was 0.60 , sapling was 0.0 , pole was 0.0 and under storey was 0.92 , while in Fibric 2, species richness of seedling was 0.43 , sapling was 0.0 , pole was 0.0 and under storey was 0.95 (Table 6 ).

\section{Species Diversity ( $\left.H^{\prime}\right)$}

Three months following burning in Fibric 1, species diversity of seedling was 1.16 , sapling was 0.0 , pole was 0.0 and under storey was 1.24, while in Fibric 2, species diversity of seedling was 0.97 , sapling was 0.0 , pole was 0.0 and under storey was 1.28 (Table 6).

Six months following burning in Fibric 1 , species diversity of seedling was 1.10 , sapling was 0.0 , pole was 0.0 and under storey was 1.49 , while in Fibric 2, species diversity of seedling was 0.80 , sapling was 0.0 , pole was 0.0 and under storey was 1.52 (Table 6).

\section{Evenness (E)}

Three months following burning in Fibric 1, evenness of seedling was 0.67 , sapling was 0.0 , pole was 0.0 and under storey was 0.77 , while in Fibric 2, evenness of seedling was 0.69 , sapling was 0.0 , pole was 0.0 and under storey was 0.72 (Table 6 ).

Six months following burning in Fibric 1 plot, evenness of seedling was 0.80 , sapling was 0.0 , pole was 0.0 and under storey was 0.76 , while in Fibric 2, evenness of seedling was 0.72 , sapling was 0.0 , pole was 0.0 and under storey was 0.78 (Table 6).

\section{Index of Similarity (IS)}

Before burning and three months following burning Index of similarity of seedling in Fibric 1 was 40.88, sapling was 0.0 , pole was 0.0 and under storey was 43.46 , while in Fibric 2, Index of similarity of seedling was 39.42 , sapling was 0.0 , pole was 0.0 and under storey was 32.89 (Table 7).

Before burning and six months following burning Index of similarity of seedling in Fibric 1 was 36.38, sapling was 0.0 , pole was 0.0 and under storey was 39.68 , while in Fibric 2, Index of similarity of seedling was 31.14, sapling was 0.0 , and under storey was 40.21 (Table 7 ).

Three and six three months following burning Index of similarity of seedling in Fibric 1 was 93.80 , sapling was 0.0 , pole was 0.0 and under storey was 82.72 , while in Fibric 2, Index of similarity of seedling was 88.38, sapling was 0.0 , and under storey was 83.17 (Table 7 ).

\section{DISCUSSION}

High fire intensity resulted during burning that vary from $5,300.28$ to $6721.24 \mathrm{~kW} / \mathrm{m}$ was an indicator how severe fire did in fibric site and it relation to the effect of the materials found both dead and live on the peat surface eventhough it was found that both fuel load was not significantly different. No peat burnt found in the site after burning even though flame temperature vary from $875^{\circ} \mathrm{C}$ to $900^{\circ} \mathrm{C}$ actually would like to show how peat with the lowest level of decomposition and covered with high moisture content was not easily be destroyed. This has consequences that during burning it will create more devastated effect on the peat surface rather than below especially in relation to the seed lethal temperature. By the way low rate of the spread of fire as a result from penetration heat that vary from $1.47 \mathrm{~m} /$ minute to 3.31 $\mathrm{m} /$ minute, give a consequence also to the performance of living things under peat surface as it had been found that flame temperature $1 \mathrm{~cm}$ below peat was vary from 75 to $90^{\circ} \mathrm{C}$. The natural regeneration emerge after burming directly affected both by heat effect on the peat surface and below and also vegetation performance near the burnt site. The effect of fire depends on the fire regime. A change in the fire regime can change the prospect of the communities (Bond and Wilgen, 1996). 
Table 4. Important Value Index Seedling 3 and 6 months following burning

\begin{tabular}{|c|c|c|c|c|c|c|}
\hline No & Botanical name & $K$ (ind/ha) & KR (\%) & $\bar{F}$ & FR (\%) & IVI \\
\hline \multicolumn{7}{|c|}{ Three months } \\
\hline 1. & Euginia jambos & 61 & 53.043 & 0.417 & 35.714 & 88.758 \\
\hline 2. & Garcinia rostrata & 32 & 27.826 & 0.333 & 28.571 & 56.398 \\
\hline 3. & Parastemon uruphyllus & 5 & 4.348 & 0.167 & 14.286 & 18.634 \\
\hline \multirow[t]{3}{*}{4.} & Antidesma pentandrum & 17 & 14.783 & 0.250 & 21.429 & 36.211 \\
\hline & & 115 & 100.000 & 1.167 & 100.000 & 200.000 \\
\hline & \multicolumn{6}{|l|}{ Six months } \\
\hline & Euginia jambos & 161 & 64.400 & 0.667 & 38.095 & 102.495 \\
\hline & Garcinia rostrata & 47 & 18.800 & 0.250 & 14.286 & 33.086 \\
\hline & Parastemon uruphyllus & 15 & 6.000 & 0.500 & 28.571 & 34.571 \\
\hline \multirow{2}{*}{\multicolumn{2}{|c|}{ 4. Antidesma pentandrum }} & 27 & 10.800 & 0.333 & 19.048 & 29.848 \\
\hline & & 250 & 100.000 & 1.750 & 100.000 & 200.000 \\
\hline
\end{tabular}

Table 5. Important Value Index Understorey vegetation 3 and 6 months following burning

\begin{tabular}{lccccc}
\hline \multicolumn{1}{c}{ Botanical name } & D (ind/ha) & DR (\%) & F & FR (\%) & IVI \\
\hline months & 445 & 59.651 & 0.583 & 24.138 & 83.789 \\
Cyperus halpan & 21 & 2.815 & 0.250 & 10.345 & 13.160 \\
Erechites valeriantnifolia & 48 & 6.434 & 0.250 & 10.345 & 16.779 \\
Melastoma malabtricum & 47 & 6.300 & 0.250 & 10.345 & 16.645 \\
Nephorlepis radicans & 79 & 10.590 & 0.417 & 17.241 & 27.831 \\
Pandanus immersus & 88 & 11.796 & 0.500 & 20.690 & 32.486 \\
Stenochalaena palustris & 18 & 2.413 & 0.167 & 6.897 & 9.309 \\
Trycalsia sp. & 746 & 100.000 & 2.417 & 100.000 & 200.000 \\
& & & & & \\
6 months & 632 & 51.174 & 0.667 & 18.605 & 69.779 \\
Cyperus halpan & 58 & 4.696 & 0.417 & 11.628 & 16.324 \\
Erechites valeriantnifolia & 70 & 5.668 & 0.500 & 13.953 & 19.622 \\
Melastoma malabtricum & 102 & 8.259 & 0.583 & 16.279 & 24.538 \\
Nephorlepis radicans & 183 & 14.818 & 0.583 & 16.279 & 31.097 \\
Pandanus immersus & 152 & 12.308 & 0.583 & 16.279 & 28.587 \\
Stenochalaena palustris & 38 & 3.077 & 0.250 & 6.977 & 10.054 \\
Trycalsia sp. & 1235 & 100.000 & 3.583 & 100.000 & 200.000 \\
\hline
\end{tabular}

Table 6. Index of species biodiversity in Fibric 1 and 3 before and following burning

\begin{tabular}{|c|c|c|c|c|c|}
\hline \multirow{2}{*}{ No } & \multirow{2}{*}{ Growth stage } & \multirow{2}{*}{ Index } & \multirow{2}{*}{ Before } & \multicolumn{2}{|c|}{ Following burning } \\
\hline & & & & Three months & Six months \\
\hline \multicolumn{6}{|c|}{ Fibric 1} \\
\hline & & $\mathbf{R}$ & 2.27 & 0.71 & 0.60 \\
\hline \multirow[t]{3}{*}{1} & Seedling & $\mathrm{H}$ & 1.77 & 1.16 & 1.10 \\
\hline & & E & 0.84 & 0.67 & 0.80 \\
\hline & & $\mathrm{R}$ & 2.32 & 0.00 & 0.00 \\
\hline \multirow[t]{3}{*}{2} & Sapling & $\mathrm{H}$ & 1.97 & 0.00 & 0.00 \\
\hline & & $\mathrm{E}$ & 0.77 & 0.00 & 0.00 \\
\hline & & $\mathrm{R}$ & 0.91 & 0.00 & 0.00 \\
\hline \multirow[t]{2}{*}{3} & Pole & $\mathrm{H}$ & 0.64 & 0.00 & 0.00 \\
\hline & & $E$ & 0.00 & 0.00 & 0.00 \\
\hline 4 & Under storey & $\mathrm{R}$ & 0.60 & 0.66 & 0.92 \\
\hline
\end{tabular}




\begin{tabular}{|c|c|c|c|c|c|}
\hline & & $\mathrm{H}$ & 1.24 & 1.24 & 1.49 \\
\hline & & $E$ & 0.90 & 0.77 & 0.76 \\
\hline \multicolumn{6}{|c|}{ Fibric 2} \\
\hline & & $\mathbf{R}$ & 2.04 & 0.53 & 0.43 \\
\hline \multirow[t]{3}{*}{1} & Seedling & $\mathbf{H}$ & 1.71 & 0.97 & 0.80 \\
\hline & & $\mathrm{E}$ & 0.88 & 0.69 & 0.72 \\
\hline & & $\mathbf{R}$ & 1.93 & 0.00 & 0.00 \\
\hline \multirow[t]{3}{*}{2} & Sapling & $\mathbf{H}$ & 1.77 & 0.00 & 0.00 \\
\hline & & $\mathbf{E}$ & 0.77 & 0.00 & 0.00 \\
\hline & & $\mathrm{R}$ & 1.44 & 0.00 & 0.00 \\
\hline \multirow[t]{3}{*}{3} & Pole & $\mathrm{H}$ & 0.69 & 0.00 & 0.00 \\
\hline & & $\mathbf{E}$ & 0.00 & 0.00 & 0.00 \\
\hline & & $\mathbf{R}$ & 0.65 & 0.86 & 0.95 \\
\hline \multirow[t]{2}{*}{4} & Under storey & $\mathrm{H}$ & 1.25 & 1.28 & 1.52 \\
\hline & & $\mathbf{E}$ & 0.90 & 0.72 & 0.78 \\
\hline
\end{tabular}

Table 7. Index of Similarity (IS) in Fibric 1 and 2

\begin{tabular}{|c|c|c|c|}
\hline \multirow{2}{*}{ Growth stage } & \multicolumn{3}{|c|}{ Index of Similarity (IS) } \\
\hline & $\overline{A+B}$ & $A+C$ & $B+C$ \\
\hline \multicolumn{4}{|l|}{ Fibric 1} \\
\hline \\
\hline a. Seedling & 40.88 & 36.38 & 93.80 \\
\hline b. Sapling & 0.00 & 0.00 & 0.00 \\
\hline c. Pole & 0.00 & 0.00 & 000 \\
\hline 2.Under storey & 43.46 & 39.68 & 82.72 \\
\hline \multicolumn{4}{|l|}{ Fibric 2} \\
\hline \\
\hline a. Seedling & 39.42 & 31.14 & 88.38 \\
\hline b. Sapling & 0.00 & 0.00 & 0.00 \\
\hline & 0.00 & 0.00 & 0.00 \\
\hline 2.Under storey & 32.89 & 40.21 & 83.17 \\
\hline
\end{tabular}




\section{Important Value Index}

\section{Seedling}

Fire drastically changed the structure and composition of seedling as it can be seen three months following burning. The site was dominated by Euginia jambos with IVI= 88.758 followed by Garcinia rostrata with IVI= 56.398 where before burning the site was dominated by Uncaria glabrata with IVI= 91.003 followed by Parastemon uruphyllus with IVI $=20.394$. At this time only four species found compared to ten species found before burning.

Six months following burning again only four species found but with more individu (250) compared to at three months (115). This fact shown that only this four species that could adapted with new environment which then dominated the site. For many species, the combination of open space, increased availability of resources and temporary reduction in seed predators (enemy-free space) is highly favourable for seedling establishment in the post-fire environment (Bond and Wilgen, 1996).

\section{Under storey vegetation}

Three months following burning under storey vegetation was dominated by Cyperus halpan with IVI= 83.789 followed by Stenochalaena palustris with IVI= 32.486 , compared to the condition before burning seems that following burning the number of species increased to be seven species than four species before. Cyperus halpan was a new species of under storey that was not found at before burning stage and dominated the site. Another new species found were Melastoma malabtricum and Trycalsia sp. Derris heterophylla that found before burning become disappeared at three months following burning. Cyperus halpan still dominated at six months following burning which then followed by Pandanus immersus that was dominated the Fibric site before burning.

\section{Species Richness (R)}

Species Richness of seedling three months following burning that was vary from 0.53 (Fibric 2) to 0.71 (Fibric 1) was lower than before burning that was vary from 2.04 (Fibric 2) to 2.27 (Fibric 1), sapling was 0.0 , pole was 0.0 and under storey was vary from 0.06 (Fibric 1) to 0.86 (Fibric 2). This fact show that fire decreased species richness of seedling, sapling, pole and under storey vegetation, even though there was an increasing of it but it was still lower than in the condition before burning. This situation was occurred also for the seedling, sapling, pole, and under storey vegetation at six months following burning condition. Even though during three months seems species richness especially for seedling and under storey vegetation increased but still lower than before burning.

\section{Species Diversity $\left(H^{\prime}\right)$}

Fire decrease species diversity of seedling, sapling, pole, and under storey vegetation as it can be seen trough species diversity performance at three and six months following burning. The increasing of species diversity during three and six months following burning could be understood because of better environmental condition resulted following burning. It was separated also by the regeneration process that occurred due to better media and environmental factor.

\section{Evenness (E)}

Evenness at the period of three months following burning was lower than in the before burning condition. Evenness of seedling was vary from 0.67 (fibric 1) to 0.69 (Fibric 2), sapling was 0.0 , pole was 0.0 and under storey vegetation that was vary from 0.72 (Fibric 2) to 0.76 (Fibric 1), there all value less than before burning value of evenness. This situation was also the same at the period of six months following burning.

\section{Index of Similarity (IS)}

Index of Similarity of seedling between before burning and three months following burning was vary from $39.42 \%$ (Fibric 2) to $40.88 \%$ (Fibric 1) sapling was 0.0 , pole was 0.0 , and under storey that was vary from $32.89 \%$ (Fibric 2) to $43.46 \%$ (Fibric 1). This means that communities formed at the three months following burning was totally different compared to the before burning condition.

Meanwhile index of similarity of seedling between before burning and six months following burning was vary from $31.14 \%$ (Fibric 2) to $36.38 \%$ (Fibric 1), sapling was 0.0 , pole was 0.0 , and under storey vegetation that was vary from $39.68 \%$ (Fibric 1 ) to $40.21 \%$ (Fibric 2). Again this fact show that communities formed at six months following burning was totally different compared to the before burning condition.

Even though communities formed at three and six months following burning compared to the condition before burning was totally different but index of similarity between seedling at three and six months following burning was vary from $88.38 \%$ (Fibric 2) to $93.80 \%$ (Fibric 1), sapling was 0.0 , pole was 0.0 , and under storey was vary from $82.72 \%$ (Fibric 1) to $83.17 \%$ (Fibric 2) means that seedling in both communities relatively the same as it occurred also in under storey vegetation but not for sapling and pole that totally different. Post-fire conditions have many advantages for seedlings, space is freed by the burning of established plants, resources increased and seed and seedling predators decline (Bond and Wilgen, 1996).

\section{CONCLUSION}

Burning drastically changes the domination and composition structure of the vegetation in fibric peat type. After burrning there was a trend of seedling species to disappeared and replace by new species, while at understorey vegetation it was totally different because following burning the species found was increased. 
At three months following burning it was found that 9 species of seedling was disappeared and only 1 species left, while at understorey vegetation it was found that only 1 species disappeared and another 3 species left. The total species of seedling found at three months following burning was 4 species (10 species found before burning) and 7 spesies in understorey vegetation (4 species found before burning).

At three and six months following burning the species richness of seedling, sapling and pole decreased drastically compared to the condition before burning, as it was occurred also in the species diversity and evenness.

Similarity of species found before burning and following burning was totally different as it found in fibric 1 and 2, but it was not too different between seedling species found at three and six month following burning that was vary from $82.72 \%$ to $93.8 \%$.

\section{ACKNOWLEDGMENT}

Author thank to PT.Riau Andalan Pulp And Paper (PT.RAPP), PO Box 1080, Pekanbaru, Riau 28000, Indonesia, which had given chance to have a research collaboration and funding assistance.

\section{REFERENCES}

Bond, W.J and B.W.v.Wilgen. 1996. Fire and plants. Chapman and Hall. 263 pp.

Chandler, C., P. Cheney., P. Thomas., L.Trabaud., and D.Williams. 1983. Fire in forestry, Vol.1. Forest fire behavior and effects. John Wiley and Sons, Inc. New York. 450.pp

Clar, C.R and L.R. Chatten. 1954. Principles of forest fire management. Department of Natural Resources Division of Forestry. California. 200 pp.
Hess, P. 1994. Forest fire in East Kalimantan1982/1983: Effects damages and technical solutions-the potential of residual stands after affected by fire. Paper presented in the workshop of Forest Rehabilitation and Forest Protection from Fire. Samarinda, 31 January-2 February 1994.

Kartawinata, K, S.Adisoemarno, S.Riswan, and A.P.Vayda. 1981. The impact of man on a tropical forest in Indonesia. Ambio 10(2,3): 115-119

Kusmana, C and Istomo. 1995. Ekologi Hutan (Forest Ecology). Forest Ecology Laboratory. Faculty of Forestry, IPB. $190 \mathrm{pp}$.

Ludwig, A.J and Reynolds, J.F. 1988. Statistical Ecology A Primer on Methods and Computing. John Wiley and Sons, Inc. New York. 337 pp.

Odum, E.P. 1971. Fundamentals of Ecology. W.B. Sanders Co. Philadelphia. 574 pp.

Schindler, L. 1998. The Indonesian fires and SE Asean Haze 1997/98. Review, Causes and Necessary steps. Paper presented at the Asia - Pasific regional workshop on transboundary atmospheric pollution. Singapore, 27 - 28 May.

Soerianegara, I and A. Indrawan. 1998. Ekologi Hutan Indonesia. Departemen Manajemen Hutan, Fakultas Kehutanan IPB. Bogor. 104 pp

Steel, R.G and J.H. Torrie. 1981. Principles and Procedures of Statistics: A Biometrical Approach. $2^{\text {nd }}$ edition. McGraw-Hill, Inc. New York. 633 pp

Woods, P. 1987. Drought and fire in tropical forests in Sabah. An analysis of rainfall pattern and some ecological effects. In: A.Kostermans (Ed.) Proc Third Round Table Conference on Dipterocarps, Samarinda, East Kalimantan, 16-20 April 1985. Unesco, Regional office for Science and Technology for Southeast Asia, Jakarta, Indonesia, pp.367-387. 